\title{
Fragile X Mental Retardation in an Indonesian Family
}

\author{
Sultana, ${ }^{1}$ Ag. Soemantri, ${ }^{2}$ P.R.L. Lam-Po-Tang, ${ }^{3}$ Fiona Wright, ${ }^{4}$ Robert Lindeman, ${ }^{4}$ Stuart Purvis-Smith ${ }^{3}$
}

\begin{abstract}
Abstrak
Sindroma fragile X adalah penyakit retardasi mental menurun yang paling umum dan dikaitkan dengan adanya "fragile site" pada ujung akhir lengan panjang kromosom X. Dalam penelitian penyaringan untuk mencari kelainan kromosom pada siswa laki-laki retardasi mental dari sekolah luar-biasa, kami pertama kali mengidentifikasi keluarga dengan sindroma fragile X di Indonesia. Pada pemeriksaan fisik, riwayat keluarga dan pemeriksaan sitogenetika dan DNA membuktikan dua kakak beradik laki-laki dengan fenotip abnormal, positif fragile X masing-masing 3\%(Dm) dan $4 \%(P r)$. Kakak perempuan dan ibunya menunjukkan fenotip dan intelektual normal, tetapi secara sitogenetik positif untuk fragile X (6\% pada kakak perempuan dan $3 \%$ pada ibunya). Analisis molekuler meyakinkan bahwa kedua anak laki-laki tersebut adalah penderita sindroma fragile $X$, sedangkan kakak perempuan dan ibunya adalah pembawa sifat.
\end{abstract}

\begin{abstract}
Fragile $X$ syndrome is the most common form of familial mental retardation and is associated with a fragile site at the end of long arm chromosome $X$. Whilst screening for chromosomal abnormalities in mentally retarded males attending special school, we have identified the first family with a fragile $X$ syndrome, to be reported in Indonesia. Physical examination, family history, as well as cytogenetic and DNA studies identified two phenotypically abnormal brothers who were fragile $X$ positive $3 \%(D m)$ and $4 \%$ (Pr). Their sister $(\mathrm{Cl})$ and mother were phenotypically and intellectually normal but were cytogenetically positive for fragile $X(6 \%$ in the sister and $3 \%$ in the mother). Molecular analysis confirmed that both brothers were affected and that their sister and mother were carriers.
\end{abstract}

Keywords : Fragile X syndrome, mental retardation, Indonesia, Javanese, chromosome studies, restriction fragment length polymorphism, pfxa3.

\section{INTRODUCTION}

Mental retardation (MR) is a common disease which is clinically and etiologically heterogenous. MR can be divided up according to intelligence quotient (IQ) test scores into severe or moderate (IQ 50 or less) and mild (IQ 50-70), ${ }^{1-3}$ with a prevalence of about 3 per 1000 for severe mental retardation and 30 per 1000 for mild mental retardation. ${ }^{2}$ Causes of mental retardation include obstetric problems, perinatal trauma, neonatal infection and genetic abnormalities such as Down's syndrome (trisomy 21) and X-linked mental retardation (XLMR). Almost all surveys of mentally retarded persons show that males tend affected more often than females. Of all mentally retarded people, $20 \%$ are due to XLMR. ${ }^{4-6}$ About $40 \%$ of XLMR and $4 \%$ of all mental retardation have been attributed to fragile $\mathrm{X}$ syndrome. ${ }^{1,6}$ Fragile $\mathrm{X}$ syndrome is the most frequent known inherited cause of mental retardation, with an estimated prevalence in predominantly Caucasian populations ranging from $0.4 / 1000$ to $0.8 / 1000$ in males and from $0.2 / 1000$ to $0.6 / 1000$ in females. ${ }^{4,7}$

Affected individuals have minor physical abnormalities and may fail to thrive in infancy or childhood or have learning difficulties in school. These children have a reasonably long life span, but require constant care from either the family or an institution. They usually attend special schools for the mentally handicapped. Fragile X syndrome is characterized by a cytogenetically detectable fragile site which appears as

\footnotetext{
${ }^{1}$ Department of Histology, Faculty of Medicine, Diponegoro University/ Cytogenetics Unit Telogorejo Hospital, Semarang, Indonesia.

${ }_{3}^{2}$ Department of Pediatrics, Faculty of Medicine, Diponegoro University, Semarang, Indonesia.

${ }^{3}$ Cytogenetics and Cell Biology Unit, Department of Haematology, Prince of Wales Hospital, Sydney, Australia 2031.

${ }^{4}$ Department of Haematology Prince of Wales Hospital, Sydney, Australia 2031.
} 
a break near the end of the long arm of the $\mathrm{X}$ chromosome. The basic defect of fragile $\mathrm{X}$ is expansion of the number of the trinucleotide CGG repeats at the 5' end of the FRAXA gene. ${ }^{8}$

Chromosomal disorders in mentally retarded children have not been studied in Indonesia because of the lack of diagnostic facilities. While undertaking a survey of chromosomal abnormalities in mentally retarded children in Semarang, Indonesia, we identified a family with two mentally retarded males demonstrating the presence of fragile $\mathrm{X}$ chromosomes. This is the first reported family with fragile $X$ in Indonesia.

\section{MATERIALS AND METHODS}

\section{Patients}

The family was identified in the course of a screening program of MR males who appeared to be phenotypically normal. There were two brothers (Dm age 13 and Pr age 8) in a special school, reported to be intellectually handicapped. They have one $\operatorname{sister}(\mathrm{Cl}$ age 14) who is intellectually normal and attends a normal school. Both parents are alive and well (see pedigree). Findings from a physical examination including testicular measurement (comparative palpation) using testicular models of known volume (orchidometer) ${ }^{9}$ of these two brothers are shown in Table 1 .

Table 1.Clinical description of the two brothers.

\begin{tabular}{lll}
\hline & Case $1(\mathrm{Dm})$ & Case 2(Pr) \\
\hline Date of birth & $27 / 3 / 1981$ & $18 / 8 / 1986$ \\
Age at time of examination & 13 years & 8 years \\
Head Circumference & $58 \mathrm{~cm}(92 \%)$ & $53 \mathrm{~cm}(>95 \%)$ \\
Weight & $49 \mathrm{~kg}$ & $19 \mathrm{~kg}$ \\
Height & $158 \mathrm{~cm}(95 \%)$ & $112 \mathrm{~cm}(95 \%)$ \\
Long face & Yes & Yes \\
High forehead & Yes & Yes \\
Prognathism & Yes & Yes \\
Long \& prominent ears & Yes & Yes \\
Macroorchidism (testicular volume) & Yes $(>25 \mathrm{ml})$ & Yes $(4 \mathrm{ml})$ \\
Strabismus & Yes & Yes \\
Nystagmus & Yes & No \\
Cogwheel rigidity & Yes & Yes \\
Abnormal gait \& parkinsonian tremor & Yes & No \\
Stereotypic movement & Yes & No \\
Hyperactive & No & Yes \\
Autism & Yes & No \\
Shyness & Yes & Yes \\
Gaze avoidance & Yes & Yes \\
Language difficulties & Yes & Yes \\
\hline & & \\
\hline & & \\
\hline & &
\end{tabular}

\section{Blood collection}

Ten $\mathrm{ml}$ of heparinized peripheral blood were drawn from each individual for cytogenetic and DNA analysis. Blood was also screened for hypothyroidism by blotting it on special filter paper.

\section{Cytogenetic studies}

Chromosome preparations were made by culturing 10 drops of peripheral blood at $37^{\circ} \mathrm{C}$ for 72 hours in duplicate tubes each containing $5 \mathrm{ml}$ Iscove's Low Folate medium supplemented with 5\% Fetal Bovine Serum (FBS) and $0.025 \mathrm{ml}$ Phytohaemaglutinin-P (Gibco). To each tube, $0.1 \mathrm{ml}$ thymidine (final concentration $0.3 \mu \mathrm{g} / \mathrm{ml}$ ) and 3 drops colchicine (final concentration $1 \mu \mathrm{g} / \mathrm{ml}$ ) were added respectively at 24 hours and 25 minutes before harvesting. Chromosome spreads were made according to routine procedures. Chromosome analysis for fragile $\mathrm{X}$ was performed by scanning 50 unbanded Giemsa-stained metaphases. When cells with chromosome breakage in group C were found, a further 50 cells and 100 cells were counted in males and females respectively. The coordinates of positive cells were noted and the metaphases photographed. Subsequently, the slides were destained in 3:1 methanol:acetic acid, and G-banded for confirmation of the fragile X. Six further new banded cells were analyzed and another 20 cells were counted to assess structural and numerical chromosome abnormalities (Figure 1 shows one chromosome with fragile $\mathrm{X}$ in $\mathrm{Cl}$ ).

\section{Molecular studies}

DNA was extracted from peripheral blood by using the saturated salt method. ${ }^{10}$ Eight micrograms of DNA were digested with one unit of the restriction endonuclease PstI (Pharmacia) in the buffer recommended by the manufacturer together with spermidine in a total volume of $20 \mu \mathrm{l}$. Agarose gel electrophoresis was performed $(0.75 \%$ agarose, $\mathrm{x} 1$ Tris-borate EDTA buffer, 35 volts for 16 hours). An SPP1 ladder (Bresatec) and normal control DNA were included in each gel. After capillary blotting to Hybond $\mathrm{N}^{+}$(Amersham), prehybridisation was performed for one hour in rapid-hyb buffer (Amersham RPN 1636) at $65^{\circ} \mathrm{C}$. The FRAXA probe pfxa3 and an X-chromosome single locus control probe pS8 (both kindly supplied by Professor G. Sutherland, Adelaide) were prepared by ${ }^{32} \mathrm{P}$-incorporation by random hexamer priming, and hybridisation performed in the same buffer for 16 hours at $65^{\circ} \mathrm{C}$. Washing was performed in $2 \times \mathrm{SSC}$ and $0.1 \%$ sodium dodecylsulphate (SDS) three times at 


\section{(1)

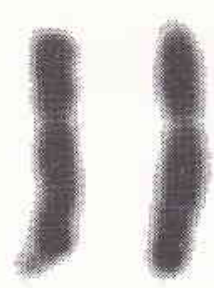

Figure 1. Fragile X chromosome (lefi) and normal X chromosome (right) in female (cl)

room temperature for 20 minutes and then twice for 30 minutes at $65^{\circ} \mathrm{C}$ in $0.1 \times \mathrm{SSC}$ and $0.1 \% \mathrm{SDS}$ Autoradiography was performed for $1-3$ days at $-70^{\circ} \mathrm{C}$ using intensification screens.

\section{Screening for hypothyroidism}

Blood was blotted on Whatman filter paper (S\&S 903 LOT\#W-621), dried and screened for hypothyroidism by Dr. Bridget Wilcken from the Oliver Latham Laboratory, Sydney.

\section{RESULTS}

\section{Clinical finding}

A family of five (2 parents and 3 siblings) was studied.Two affected brothers were examined. Both brothers had no obstetric and neonatal problems as well as stigmata of hypothyroidism. Their parents and sister were normal on physical examination. The pedigree is shown in Figure 2 and clinical features of the two brothers are presented in Table 1 and Figure 3.

\section{Cytogenetic Analysis}

Cytogenetic study of two affected sons identified a break in the long arm of the X chromosome at q 27.3 (FRAXA locus) in 100 metaphases : $3 \%$ in Dm and $4 \%$ in $\operatorname{Pr}$. The mother and daughter(Cl) had $3 \%$ and $6 \%$ fragile $\mathrm{X}$ cells in 150 metaphases respectively. No fragile sites were identified in 50 metaphases in the father.

\section{Molecular Analysis}

The Restriction fragment length polymorphism (RFLP) using the pfxa 3 probe detected a constant band between 1.0 and $1.1 \mathrm{~kb}$ in normal controls. Simultaneous hybridisation with pS8 yielded a $0.8 \mathrm{~kb}$ band which provided an intensity control for normal $\mathrm{X}$ chromosome copy number in all individuals.

In proband son $I(\mathrm{Dm})$ the normal pfxa band was replaced by $1.60 \mathrm{~kb}$ and $2.6 \mathrm{~kb}$ bands, while his brother son II (Pr) had a $2.2 \mathrm{~kb}$ but no normal band. Their sister (Cl) was a carrier, with an abnormal $2.2 \mathrm{~kb}$ and a normal $1.1 \mathrm{~kb}$ band which was also present in their father. Their mother was also a carrier, with abnormal $1.3 \mathrm{~kb}$ and normal $1.1 \mathrm{~kb}$ bands (see Figure 2).

\section{Screening for hypothyroidism}

Screening for hypothyroidism was negative for all five members of family.

\section{DISCUSSION}

We report the first recorded cases of Fragile $X$ in an Indonesian family of Javanese ethnic background. We are not aware of any previous recorded cases in In- 


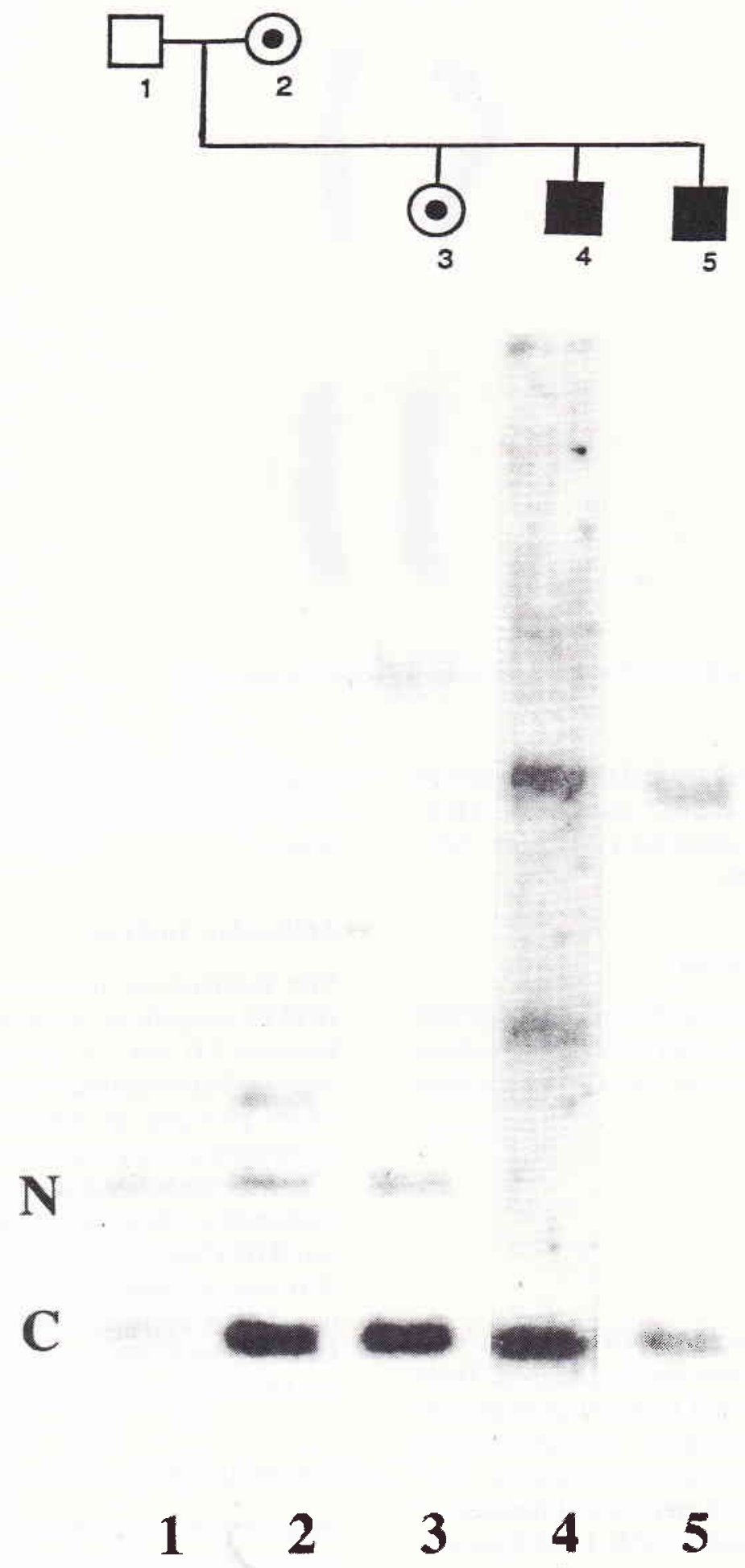

Figure 2. Shows five lines of a Southern blot. The band obtained by hybridising Pstl digested genomic DNA with the $X$ chromosome probe pS8 is used as a control (C) for densitometry, while the normal band size $(N)$ obtained using the FRAXA probe is indicated. The father (lane 1) has only a normal band, while the mother (lane 2) is a carrier, since there is an additional higher band. Each FRAXA band is of reduced density relative to the control, C. The daughter (lane 3) is also a carrier, while the sons Dוt (lane 4) and $\operatorname{Pr}$ (lane 5) lack the normal band, which has been replaced by two and one higher band respectively, they are therefore affected individuals. 


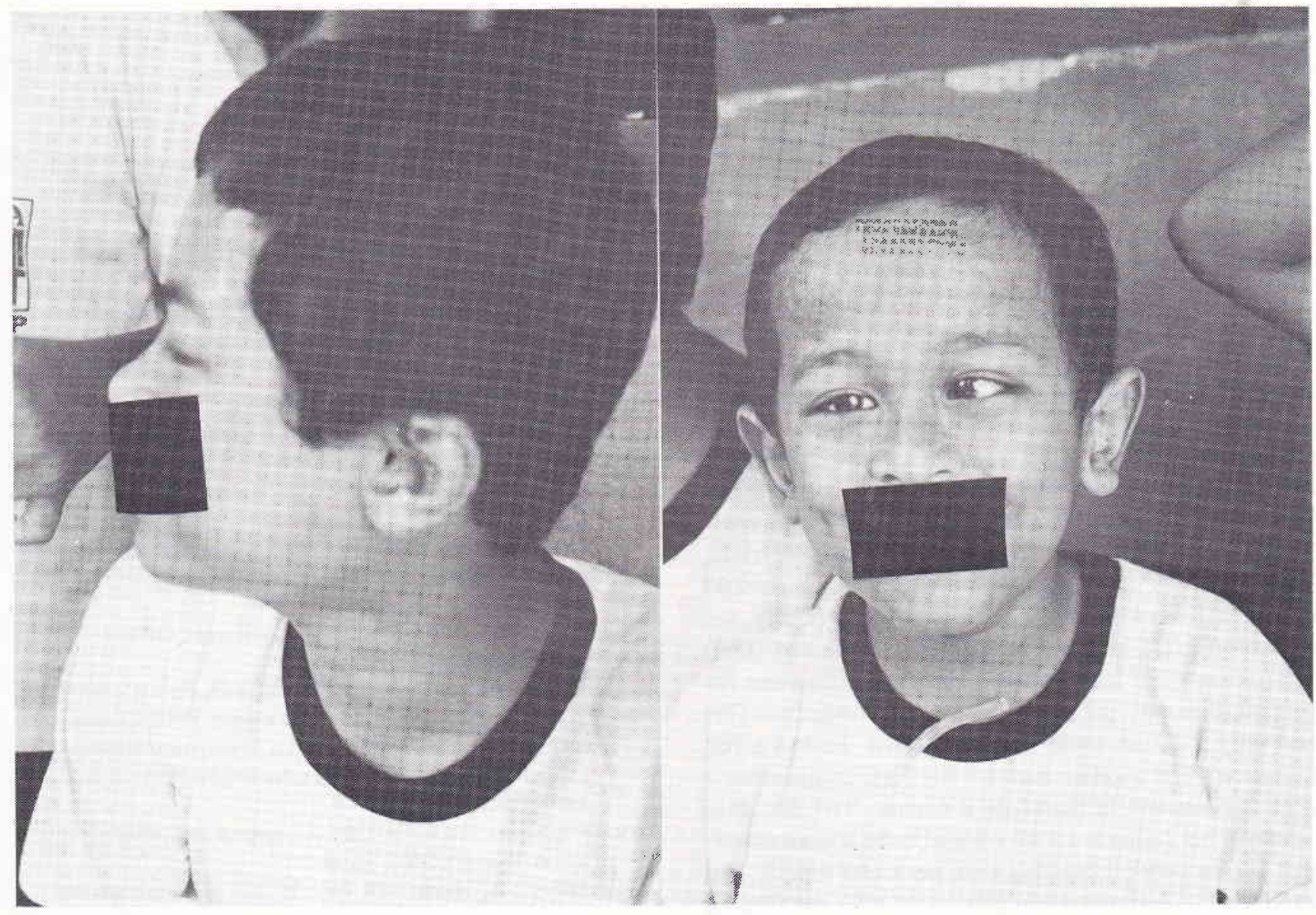

Figure 3. Two affected brothers, Dm (left) and $\operatorname{Pr}$ (right)

donesia except for a case of fragile $\mathrm{X}$ mental retardation in one Dutch-Indonesian in Hawaii, whose ethnic background was not reported. ${ }^{11}$

The affected males (Dm and Pr) showed macroorchidism. In the case of the 8 year old the testicular volume should be less than $4 \mathrm{ml}$. In the 13 years old who is showing early sign of puberty such as some pubic hair the testicular size should be $4 \mathrm{ml}$ but is already over $25 \mathrm{ml}$. Both have long ears and prominent jaws, shyness, no speech difficulties but both have language deficits such as abnormally frequent use of short sentences. These features were present in many patients of fragile $X$ syndrome. ${ }^{4,72}$ They also had strabismus and nystagmus which are occasional fea- tures in these individuals. ${ }^{4,13}$ The two affected boys have different characters: one is hyperactive and the other quiet and autistic. Both traits are seen in fragile $\mathrm{X}$ MR syndrome

The frequency of fragile $\mathrm{X}$ cells is $3 \%-4 \%$ in the affected males (two sons) appear to be lower than in other studies which reported an incidence of 2$50 \% .{ }^{1,7}$ Interestingly, the frequency of fragile cells was higher in the carrier daughter than in her affected brothers.

The fragile $\mathrm{X}$ locus is a folate sensitive fragile site. Detection is dependent on either a culture medium deficient in folate or containing an inhibitor of folate metabolism (eg.FUdR, methotrexate, excess 
thymidine) and reduced content of FBS. ${ }^{14,15,16}$ It is possible that although low folate medium was used there was enough folate and FBS in the medium to reduce the incidence of fragile $X$ expression. Recently two other folate sensitive fragile sites (FRAXE and FRAXF) were found in mentally retarded cases at Xq27-28. ${ }^{17,18,19,20}$ These new rare fragile sites can only be distinguished from the fragile $\mathrm{X}$ by DNA analysis.

DNA analysis using the probe pfxa3 and the restriction enzyme Pst $I$ is diagnostic of the fragile $\mathrm{X}$ genotype. The band size reflects the number of CGG repeats with the following finding: in non-carriers (male or female) there is a constant band of 1.0-1.1 kb; in phenotypically normal male carriers, there is a band between 1.1 and $1.6 \mathrm{~kb}$ in size representing 70-200 CGG copies. ${ }^{16,21,22}$ In affected males there are larger and/or multiple bands with the size of the band greater than about $1.6 \mathrm{~kb}$ (>200copies) together with hypermethylation of $\mathrm{CpG}$ dinucleotides. In female carriers, 70-200 copies are designated premutation and $>200$ copies a full mutation. ${ }^{16,19,23}$ In our case family, we identified a $1.1 \mathrm{~kb}$ band in the father. One son (Dm) had 1.6 and $2.6 \mathrm{~kb}$ bands suggesting mosaicism for premutation and full mutation, while the other son (Pr) had only a $2.2 \mathrm{~kb}$ band indicating that he had a full mutation. The mother had $1.3 \mathrm{~kb}$ band suggesting a premutation and is therefore a carrier. The daughter who had her father's $1.1 \mathrm{~kb}$ normal band and an abnormal $2.2 \mathrm{~kb}$ band, indicating that her CGG repeats had expanded to full mutation, consistent with the finding of others in the literature that there is a progression of expansion from one generation to the next. ${ }^{2,19,22}$

The implications of these findings are that other members of the family, in particular aunts and uncles of the proposita should be studied to determine the origin of the fragile X. Genetic counseling can then be promoted for members of the family who have been investigated.

\section{Acknowledgments}

We are grateful to the Rector of Diponegoro University, Dean of Medical Faculty of Diponegoro University and Director of Six Universities Development Rehabilitation Project who supported this study. We thank the Director of Telogorejo Private Hospital Semarang and the Cytogenetics Unit staff who helped in the collection, preparation of samples and provided the laboratory in which cytogenetic studies were performed. We thank the members of the Fragile $X$ Department, Prince of Wales Hospital Prof. Gillian Turner, Dr. Samantha Wake and Ms. Hazel Robinson for discussions. Particular thanks are extended to the head of Dharma Bhakti foundation and the teachers at the Dharma Bhakti Special School, for their willingness to participate in this study.

\section{REFERENCES}

1. Connor JM, Ferguson-Smith MA. Essential Medical Genetics. 4th ed. Oxford, Blackwell Scientific Publications, 1993; 123:148-9.

2. Harper PS. Practical Genetic Counselling. 4th ed. Oxford, Butterworth Heinemann, 1993; 185-91.

3. Thapar A, Gottesman II, Owen MJ, O'Donovan MC, McGuffin P. The Genetics of Mental Retardation. Brit J Psy 1994; 164: 747-58.

4. Hagerman RJ, Silverman AC (ed). Fragile X syndrome diagnosis, treatment, and research. Baltimore: The Johns Hopkins University Press, 1991.

5. Turner G, Turner B. X -linked mental retardation. Am J Med Gen 1974; 11: 109-13.

6. Mikkelsen M. Sex-linked mental retardation. In : Vogel F, Sperling K (ed). Human Genetics. Berlin,Springer-Verlag, 1987; 441-9.

7. Davies KE. The Fragile X syndrome. Oxford: Oxford University Press, 1989.

8. Verkerk AJMH, Pieretti M, Sutcliffe JS, Fu YH, Kuhl DPA, Pizzuti A, et al. Identification of a gene (FMR-1) containing a CGG repeat coincident with a breakpoint cluster region exhibiting length variation in the fragile $\mathrm{X}$ syndrome. Cell 1991; 65: 905-14.

9. Prader A. Testicular size: Assesment and clinical importance. Triangle 1966; 7:240-3.

10. Miller SA, Dykes DD, Polesky HF. A simple salting out procedure for extracting DNA from human nucleated cells. Nucleic Acids Research 1988; 16:1215.

11. Rhoads FA. Fragile $X$ syndrome in Hawaii: a summary of clinical experience. Am J Med Gen 1984;17: 209-14.

12. Jenkins EC, Shapiro LR, Brown WT. Prenatal Diagnosis of The Fragile X syndrome. In: Milunsky A, (ed). Genetic disorders and the fetus, diagnosis, prevention and treatment. Baltimore: The Johns Hopkins University Press, 1992 ;24155.

13. Chudley AE, Hagerman RJ. Fragile X syndrome, medical progress. Ped, 1987;110:821-31.

14. Sutherland GR, Hecht F. Fragile sites on human chromosome, Oxford: Oxford University Press, 1985.

15. Sutherland GR, Baker E, Fratini A. Excess thymidine induces folate sensitive fragile sites. Am J Med Gen 1985; 22 : 433-43.

16. Richards RI, Sutherland GR. Fragile X syndrome. The molecular picture comes into focus. Trends in Genetics 1992; 8: 249-55.

17. Knight SJL, Flannery AV, Hirst MC, Campbell L, Christodoulou Z, Phelps SR, et al, Trinucleotide repeat amplification and hyper methylation of a $\mathrm{CPG}$ island in FRAXE mental retardation. Cell 1993;74: 127-34.

18. Sutherland GR, BakerE. Characterisation of a new rare fragile site easily confused with the fragile $X$. Human Molecular Genetics 1992; 1:111-3. 
19. Hirst MC, Barnicoat A, Flynn G, Wang Q, Daker M, Buckle VJ, et al: The identification of a third fragile site, FRAXF, in Xq27-q28 distal to both FRAXA and FRAXE. Human Molecular Genetics 1993; 2: 197-200.

20. Bates $G$, Lehrach $H$. Trinucleotide repeat and human genetic disease. BioEssays 1994; 16: 277-83.

21. Sutherland GR, Gedeon A, Kornman L, Donnelly A, Byard RW, Mulley JC, et al. Prenatal Diagnosis of fragile X syndrome by direct detection of the unstable DNA sequence. New England J Med.; 1991: 1720-22.

22. Yu S, Pritchard M, Kremer E, Lynch M, Nancarrow J,Baker $\mathrm{E}$ et al. Fragile $\mathrm{X}$ genotype characterized by an unstable region of DNA. Science 1991; 252: 1179-81.

23. Taylor A, Safanda JF, Fall MJ, Quince C, Lang KA, Hull CE et all. Molecular predictors of cognitive involvement in female carriers of fragile X syndrome. Jama SEA; June 1994: 25-31. 